\title{
Network Governance in Russia: An Analytical Framework
}

Authors:

Jonathan S. Davies, Department of Politics and Public Policy, Faculty of Business and Law, De Montfort University, Leicester [Leicester LE1 9BH, UK; jsdavies@dmu.ac.uk phone: +44 0116 $2577818]$

Jørn Holm-Hansen, Norwegian Institute for Urban and Regional Research, Oslo and Akershus University College of Applied Sciences

[Gaustadalléen 21, N-0349 Oslo, Norway; jorn.holm-hansen@nibr.hioa.no; phone: +47 2295 $8800]$ (corresponding author)

Vadim Kononenko, European Parliament's directorate general for external policies, Brussels [Bât. Altiero Spinelli, 60 rue Wiertz, B-1047 Bruxelles, Belgium;

vadim.kononenko@europarl.europa.eu; phone +32(0)2 28 42111]

Asbjørn Røiseland, Norwegian Institute for Urban and Regional Research and University of Nordland [Faculty of Social Sciences, Box 1490, N-8049 Bod $\varnothing$, Norway; asr@uin.no; phone $+4775517624]$

Biographical notes:

Jonathan Davies is Professor of Critical Policy Studies at De Montfort University, Leicester, UK. He has published widely on governance theory and is currently leading a major ESRC study on austerity governance in eight countries. He is Director of De Montfort University's Centre for Urban Research on Austerity. 
Jørn Holm-Hansen is a political scientist and senior researcher and at the Norwegian Institute for Urban and Regional Research (NIBR). His research concentrates on political and administrative processes in Russian and East European countries. He is currently the leader of a three-year international project on welfare reforms and political mobilisation in Russia.

Vadim Kononenko currently works at the European Parliament's directorate general for external policies. His previous employment was with the Finnish Institute of International Affairs where he conducted research on governance in Russia, particularly in the field of energy policies. He is a co-editor of Russia as a Network State. What works in Russia when state institutions do not? Palgrave 2011.

Asbjørn Røiseland is a senior researcher at the Norwegian Institute for Urban and Regional Research (NIBR) and professor in political science at University of Nordland. His main research interests are local and regional governance and democracy, including network governance and partnerships. Among his research projects are several comparative studies, including comparative studies of local governance in Canada, Russia, and Norway. 


\section{Abstract}

This article questions the widely held notions of Russian exceptionalism as regards its statesociety relations, arguing that the conceptual tools used to study governance in other regions and contexts are applicable in Russia, opening the potential for fruitful comparisons and dialogue. We develop an analytical framework for studying Russian governance, placing special emphasis on the concept of networking. We posit that even in contemporary hybrid authoritarian regimes the state is dependent to an extent on interactive governance arrangements involving civil society actors. The article applies the analytical framework to an initial synthesis of findings from studies of Russian governance, reported in depth elsewhere in the Symposium. The research demonstrates that networking with domestic civil society organisations, when sanctioned and deemed useful, subsists alongside state-centred modes of governing. This co-existence should not be exaggerated, but it is nonetheless important. Russia has therefore developed a special relationship with its civil society, like other hybrid authoritarian regimes.

Keywords: Russia, network, governance, state, civil society, regime 


\section{Introduction}

This article develops an analytical framework for re-examining state-civil society relations in Russia through a critical application of network governance theory. It applies this framework in synthesising the findings from two research projects on network governance in Russia, funded by the Research Council of Norway's NORRUSS Programme and the Metro Foundation. The research has been carried out in collaboration between researchers from Russia, Germany, Finland, Great Britain, and Norway. The symposium explores five Russian policy areas: migration and integration; drug policy; child protection; environmental impact assessment (EIA); and ethnic policies. Research has been carried out in the Russian regions of St Petersburg, Samara, Krasnodar, Stavropol, Irkutsk, Perm, and Nizhnyi Novogorod.

The premise of our research was that Russia can fruitfully be studied by employing concepts familiar in the study of governance worldwide, including the tools of network analysis (e.g., Rhodes, 1997). The central contributions of this article are twofold. First, it presents the framework for analysing technologies of hybrid governance employed in Russia today. Second, we apply the analytical framework to produce an initial synthesis of findings from the empirical research. The synthesis demonstrates that the Russian state depends, to an extent, on cultivating networks. Although Russian civil society actors are relatively weak (Belyaeva and Proskuryakova 2008), they nevertheless play a meaningful and specific role in the country's governance. The study therefore suggests that the "hybrid regime" (Petrov, Lipman and Hale 2010) confronts dilemmas familiar to scholars and practitioners of governance globally, albeit with a distinctly Russian flavour. The article begins by explaining the rationale for the study and then develops the analytical framework in two steps: exploring approaches to network governance theory; and situating networks in a broader 
typology of governance technologies. The final section synthesises findings from the study reported in the Symposium and highlights questions for further research.

\section{State and Society in Russia}

Our inquiry begins at the intersection of Russia's policy-making structures and the policy challenges it faces. Our concern is not with "dark" networks such as corrupt, complex, overlapping, and often conflictual relations among state and corporate elites (Raab and Milward 2003; Kononenko and Moshes 2011), or equally convoluted relations between the state and civil society organisations funded by foreign donors and forced to register as 'foreign agents'. Rather, we will focus on the poorly understood practices of interaction, or networking, among state and domestic civil society groups active in several Russian policy areas (migration and integration, drug policy, child protection, EIA, and ethnic policies). The state-civil society perspective directs our attention to core issues in "traditional" scholarly works on Russia, but from a novel standpoint.

A frequently cited reason for doubting that Russia can be analysed with the conventional, network-focused governance heuristics is the historic weakness of its civil society. Gramsci conceived government and civil society as inter-dependent, defining the "integral state" (1971: 262-3) as the sum of "political society + civil society". " Political society" is the sphere of government within the "public" domain of the state, and "civil society" the assemblage of "so-called private organisations, like the church, trade unions, schools and so on" (Gramsci, 1971: $56 f n$ ). The theory of the integral state was Gramsci's solution to the puzzle of why Western nations proved immune to Bolshevism. Capitalist hegemony depends on the coercive apparatus, but is sustained day-to-day through the combined ideological work of government and powerful non-governmental organisations, 
most notably the media, church, and trusts, constituting "the state in an organic and larger sense" (Thomas, 2009: 96). Gramsci saw civil society in Russia and the east as "primordial and gelatinous", rendering it vulnerable to Bolshevism (Gramsci 1971: 238). Later 20th century writing on Russia and the Soviet Union also treats civil society as residual, because of the overweening and repressive presence of the state in all spheres of life. Russia was essentially and deeply "autocratic" (Pipes 1995, 1999), and still today, civil society organisations in Russia remain weak (Belyaeva and Proskuryakova 2008; Evans 2012). However, our guiding hypothesis is that there is more to civil society in the $21^{\text {st }}$ century than in the classical Gramscian view, and that the study of government-civil society relations will cast a new light on the governance of Russia. On closer inspection, the seemingly authoritarian and paternalistic mode of governance in Russia includes a host of interactive practices: co-optation, negotiation, and networking between state and non-state actors. It is this empirical observation that leads us to focus not on what differentiates Russia - although always mindful of this - but rather what it might have in common with other countries in seeking to handle policy challenges through more or less authentic interactions with civil society actors. For example, some theorists highlighted the need for state-society interactions even under so-called "state socialism". Richard Sakwa (1998: 185) described a transformatory state that had to adapt to - make peace with - its social surroundings. The transformatory project was made ideological, whilst adaptive processes were de-ideologised (Sakwa 1998:185). Stark and Bruszt (1998) drew attention to the need for the state to nurture and cooperate with non-state actors, to keep the wheels in motion during the shortage economy of the time. More broadly, as Davies (2012: 2700) argued, "it is hard to see how even extreme hierarchies, such as North Korea, could survive without a modicum of networking and trust". For the analysis of contemporary Russia, the latter strand of 
literature implies that state-society-business interactions did not have to be re-invented after 1991, but rather drew upon and adapted earlier practices and traditions.

Russia therefore confronts policy-making challenges with an institutional/structural and informal heritage that to an extent delineates contours of governmental and nongovernmental networks. These networks help the state address problems the state cannot adequately solve without mobilising civil society resources, including expert advice, policy ideas, organisational resources, and the capacity to enhance legitimacy - which also contribute to its durability. Today's "hybrid regime" has to address challenges the state cannot adequately solve without to a certain degree drawing on civil society resources, as shown in Brian Taylor's (2014) study on police reform 2009-2011 and Kirsti Stuvøy’s (2014) study on the Public Chamber in Murmansk.

We see two further grounds for supporting and refining this conjecture. First, throughout its imperial, Soviet, and post-Soviet periods, the Russian leadership has sought in different ways to achieve administrative regularity and public order through promotion - from above - of state-civil order, rational regulation of law and the economy, and refined social norms (Malia 1999:28). In fact, Russia's public administration may at times seem obsessed with formalities. At the same time, it appears ready to take informal shortcuts when needed by cooperating with other actors. Sakwa $(2010 a, 2010 b)$ captures this duality by distinguishing Russia's formal "normative state" and its "administrative regime". The collaborative governance we aim to shed light on is likely to be more prevalent in the administrative regime than the normative state (although present also in the latter), such as formalised public chambers and consultative councils. 
Second, the developmental trajectory of Russia's state bodies, businesses, professional associations, and voluntary groups are quite different from those in the West, and the circumstances under which policy networks develop differ - not least in the face of policy vacillations. Since the demise of the USSR, Russia has been through periods of denigrating the state (Hedlund 2001; Shlapentokh 2003), vigorous attempts to cultivate civil society from above (Henry and Sundstrom 2006), and a renewed period of nationalist authoritarianism, combined with more or less effective consultative mechanisms (Petrone 2011). Despite the latest authoritarian turn, this history of policy churn and U-turns may have left deficits in state capacity, leading the authorities to seek collaboration with civil society organisations. These collaborations, however, are almost exclusively done in contexts where the state not only sets he terms of engagement, but also often creates the civil society with which to engage. The latest scholarship on Russia's governance conceptualises this duality in terms of "substitutions", i.e., compensating for the lack of functioning formal state institutions and resolving the potential tension between the state and societal actors by creating hybrid actors where the state does not have formal ownership rights but maintains the control stake (Petrov, Lipman and Hale 2014). In fact, there may be a parallel between Russia's "substitution" and the tendency elsewhere to let "network governance" substitute processes and procedures of representative democracy.

\section{Russia's Governance Challenges}

The "hybrid governance" model in Russia is not unique. Former state socialist countries have experienced two and a half decades of functional differentiation, specialisation, privatisation, and the semi-privatisation of public agencies (Randmaa-Liiv 2008; Randma-Liiv, Nakrošis and György 2011). The fact that the public sector has been reformed in this way 
enhances the case for researching state-civil society cooperation in more depth and considering the relevance of network governance theories. Some former public bodies are now semi-private firms, at times with a non-governmental organisation (NGO) attached to them. Fragmentation may lead to new attempts at co-ordination. At the same time, the narrative of increased "complexity" used to warrant network governance in Northern Europe can also be traced in Russian policy discourses (e.g. Elbakidze et al. 2010), leading us to consider whether they too represent networking as part of the solution (see below for a discussion of problem and actor-centred approaches to network governance).

Russian legislation and policies reflect a policy of enabling cooperation between public, societal, and market sectors (Jakobson and Sanovich 2010; Hemment 2012; Chebankova 2013; Crotty, Hall \& Ljubownikow 2014; Daucé 2014). This has been particularly evident in social welfare. The overall Russian welfare system is under reform. Despite the official rhetoric on "sovereign democracy", "Russia following its own way", and so on, reforms bear the clear stamp of international inspiration. Greater market provision and less public provision form part of these welfare reforms, and these tendencies have gained speed since the turn of the millennium (Cook 2013:3; Tarasenko 2015; Bindman 2015).

The clamp down on NGOs financed from abroad (the so-called "foreign agents" law enacted in 2012) was simultaneously combined with a grant scheme for domestic funding. In 2005, the Law no. 32-FZ "On the Public Chamber" introduced this institution: to manage societal expertise, societal initiatives and control; to distribute grants to civil society organisations; and to present an annual report on civil society (Tarasenko 2010; Petrone 2011; Chebankova 2013: 110). One of the main functions of the Public Chamber, which operates at the regional and federal scales, is to secure what the Russian literature (Vasil'eva 2009; Tipalo 2011) 
terms "public control" of the state apparatus, legislation, and policies. By carrying out these functions, the Public Chamber takes on a role to some extent resembling the intricate system of public hearings and NGO, trade union, and expert involvement found in Nordic countries. Owen (2015) shows how human rights activists join Public Monitoring Commissions for created by the state to perform "public control" by overseeing conditions in prisons are able to effect improvements.

In his 2009 address to the Federal Assembly, President Dmitry Medvedev proposed to introduce a new category of "socially oriented NGO's" which led to Law 7-FZ "On NonCommercial Organisations" in April 2010 (Chebankova 2013:105) In July 2009, the state doctrine on charitable work, "On the support of charitable work", a document drafted with inputs from the Ministry of Economic Development, the Public Chamber, and charitable organisations. Here the state and local governments would share responsibility for supporting the non-commercial organisations financially and also for providing services (Prognostika 2011:29). Big business supports charitable organisations to show loyalty to the state and consolidate its political position (Chebankova 2013: 107).

In a study of relations between public, societal, and market sectors, Vasil'eva (2009) found evidence of cooperation based on the concepts of "equal rights, solidarity, shared responsibility, shared interests, unity of core values, and readiness to compromise". This cooperation does not remove the contradictions and differences in interests, but the idea is that the application of dialogue and compromise may help solve potential conflicts. At the same time, Vasil'eva argues that this kind of cooperation strengthens state actors' authority: there is cooperation and dialogue, but state power is not nullified. At a very local level - like the group of households in one entrance of a high-rise building or a neighbourhood - hybrid 
institutions of the so-called TOS - Territorial societal self-government - also address policy challenges. They are conceived to enable partnership between population and authorities. They can be independent organisations, non-commercial entities or NGO's (Chebankova 2013:106).

Our conjecture is therefore that social policy challenges require approaches that are not entirely "top-down", and that there are limits to the efficacy of the state. Therefore, Russia's public authorities and non-state actors including experts and NGOs must sometimes find ways of collaborating if each is to stand a chance of fulfilling their own goals. We anticipate that authorities need the legitimacy they acquire from co-operating with societal organisations, and that these organisations are often sources of valuable expertise, knowledge and skills, of voluntary man hours and alternative, additional financing. The research synthesised in the final section of the article focuses on governance arrangements involving domestically resourced civil society organisations. It lends support to our conjecture, highlighting a surprising variety of networked practices and demonstrating how different ways of governing overlap - with networks often created and nurtured by state actors, but only partially constrained by state authority, discipline, and control. To this extent, and suitably qualified, notions of network governance may make a useful contribution to understanding Russia - and to comparative research on Russia and other countries based on alternative governing systems.

\section{Networks, Governance, and Russia}

In this section, we explain our analytical framework for studying network governance in Russia. It is set out in two parts. First, we discuss salient approaches to network governance. We then seek to put network governance in its place by discussing critical reactions to the 
network governance paradigm, which show that while non-coercive networking is a common governing practice it is deeply entwined with other practices and inter-dependent (Grote, 2012). The challenge of studying governance in Russia, as it is elsewhere, is to grasp the "mix" of technologies and practices and their trajectories over time (Davies and Spicer 2014).

\section{Network governance theory and its critics}

There has been extensive research into network governance since the 1990s, concentrated in but by no means limited to Europe (e.g., Geddes 2008). Though it became fashionable only recently, the study of networks is far from new - emerging with Moreno's "sociometry" in the 1930s, as a precursor to Social Network Analysis (e.g. Borgatti et al 2009). In the mid1970s, Granovetter (1983) developed the theory of strong-weak ties, underpinning social capital and neo-institutionalist theories, highlighting the efficacy of networking for social capital, resource mobilisation, and wellbeing.

However, the explosion of network governance studies in the late 20th and early 21st centuries was far more ideologically loaded and controversial, based on claims about fundamental socio-political transformation, from hierarchical and/or command-based to network-based systems. Thinkers heralding the rise of networks pointed to several factors, such as the decline of traditions including loyalty to the state, and the increased complexity of policy making in a globalised context - the rise of the "risk society" (Beck, 1992) - and the vastly increased access to knowledge, expertise, and connectivity enjoyed by lay-citizens in the information age. As Pierre and Stoker (2002: 29) put it, 
Today, the role of the government in the process of governance is much more contingent.

Local, regional, and national political elites alike seek to forge coalitions with private businesses, voluntary associations and other societal actors to mobilize resources across the public-private border in order to enhance their chances of guiding society towards politically defined goals.

In its guise as a theory of social change, network governance is based on the assumption that the authority and capacity of states are diminishing, requiring cooperation with corporate and civil society actors in the formulation and delivery of public services. State-centred government is partly replaced by processes and practices where public, semi-public, and private resources and actors come together to pursue congruent (if not common) goals. The literature suggests two sides to these functional explanations for the proliferation of networks: problem-centred and actor-centred approaches.

For problem-centred analysts, networks are functional responses to increasing societal complexity and diversification, which weakens the capacity of states to govern efficiently through traditional means of hierarchy and the market (Sørensen and Torfing 2007:18, 2011; Mayntz 1993). One such example is the doctrine of "wicked problems" (Roberts 2000) - a concept commonly applied in the context of network governance to denote challenges so complex that they are difficult not only to solve but also to define. Networks rooted in wicked problems may take many formal or informal forms, but the approach basically stipulates that the public sector must collaborate with the market and civil society actors to address 21st century challenges (Huxham and Vangen 2005; Osborne 2010).

From the perspective of actors, network governance can alternatively be understood as a pragmatic response to fragmentation and specialization that followed neo-liberal reforms 
(Rhodes 1997). A central idea of the loose group of reform initiatives labelled under the umbrella of "New Public Management" (NPM) is that autonomous agencies or public companies cope better than classical multifunctional administrative units. From this point of view, governance networks are inter-organisational media for interest mediation between interdependent, but conflicting actors each of which has a rule and resource base of their own (Sørensen and Torfing 2007:18). The rise of network governance is more or less explicitly, understood as a critique of the modus operandi of the state in late modernity.

Problem and actor-centred explanations form an important touch point for the research discussed below. While we reject functional explanations - that networks arise because societal logics dictate that they should - we are interested in whether these or other rationales for collaboration appear in the dataset.

The influence of these perspectives in international public policy is hard to exaggerate. Policy transfer is one important mechanism by which the idea of promoting governance networks spreads around the world (Evans and Davies, 1999). Transnational institutions like the European Union, OECD, United Nations, and World Bank are vehicles for the diffusion of network governance policies and programmes. The idea of network governance has spread far beyond Europe. For example, the South African government enthusiastically promoted the idea of a state-civil society partnership, arguably inspired by New Labour in the UK (Harrison, 2006). Mexico is another country where state-organised governance networks have proliferated, influenced by global ideology, international governance institutions and policy emulation (Flores 2005: 174).

Perhaps of greatest interest for current purposes is evidence that China has been experimenting with network governance. Bray (2006) argued that becoming increasingly 
concerned about maintaining cohesion, it has adapted Western ideas about local community building and partnership. Taylor (2004: pp. 33-34) cautioned that such processes are fragile in a country where the Communist Party continues to dominate. However, our intuition was that if network governance resonates in China, perhaps it does so in Russia as well.

Nevertheless, a degree of caution is necessary. The explosion of interest in networking, as a novel or potentially transformative mode of governing, was quickly followed by a critical backlash, tempering or rejecting the "epochalist" tone of these perspectives (e.g., Marsh 2008; Davies 2012). Some scholars, like Stone (2009) pointed out that, far from being innovative, what we now call "network governance" has been evident in Western democracies since at least the dawn of universal suffrage. States have always had to cooperate with business and third-sector activists (Røiseland 2011). What has changed is the vocabulary and normative salience of collaboration. Moreover, functional explanations of the "need" for network governance pay little heed to actually-existing social forces and counter-currents that might prevent it from arising in anything more than truncated or tokenistic forms.

Critics in the Northern European heartlands of "network governance" point to multiple network pathologies, both highlighting the limitations of functional explanation and pouring cold water on extravagant claims for the emergence of a "network society". First, governance networks are often state-centred "invited spaces", where government officials select and invest in civil society organisations. When state investment dries up, networks often fail, suggesting that they are sustained by "hierarchy" (e.g. Grote 2012). The critical literatures reveal, moreover, that networks are prone to closure and elite capture by fractions of business and the professions - thereby compounding power asymmetries. 
Another strand highlights that citizen activists and voluntary sector groups are often recuperated or marginalised, particularly if they try to challenge neoliberal logics (Skelcher, Mathur, and Smith 2005). Moreover, critics argue that the levels of trust required to sustain authentic network governance among diverse interest groups do not exist. For example, Cook, Hardin, and Levy (2007: 196) argued that "societies are essentially evolving away from trust relationships towards externally regulated behaviour" - an intuition reflected in widespread contempt for political elites dubbed provocatively as "anti-politics".

\section{Network governance and the Russian context}

The limitations of network governance in its European heartlands reinforce our confidence that the theory of Russian exceptionalism is misconceived. Simply put, while Russian tropes of authoritarianism and network failure are prominent in the West, Western vocabularies of networks and collaboration populate elements of the Russian literature. Synthesising the supportive and critical perspectives on network governance provides a powerful compass for studying Russia. We adapt Ansell and Gash's (2008: 544) three-part definition of collaborative governance, using it as a proxy for network governance. Part 1 defines collaborative governance as "[a] governing arrangement where one or more public agencies directly engage non-governmental actors in a collective decision-making process". We broaden this to "collective discussion". Part 2 defines collaborative governance as "formal, consensus-oriented, and deliberative". This part is too narrow for our purposes, which incorporate formal and informal processes and a much wider range of collaborative and non-deliberative practices. Focusing on authentic deliberation would exclude a range of far more common collaborative practices associated with resource-interdependency, pragmatism and instrumental rationality. Part 3 demarcates network governance as 
processes that "make or implement public policy or manage public programs or assets'. Our study follows this element of the definition.

Finally, to ascertain the role of networking within our chosen areas, it is necessary to contextualise it with other governance technologies including coercion, hierarchy, threat, market competition, and contract. We suggest that these technologies are "universal" in the sense of comprising the modalities of coordination and regulation operating in any political system, and that an adequate analysis of the "mix" is vital for both diagnostic purposes and theory building - in this case, eliciting the salience of Russian government-civil society networks, and the reasons for this. Insofar as coercion is concerned, the martial capacities of the Russian state are evidently critical to its attempt to project power, both internally and externally. Insofar as civil society is concerned, the politics of threat, discipline and suppression remain widespread - most evocatively the designation of certain NGOs as "foreign agents". Yet even here, Russia is not entirely exceptional in keeping an eye on foreign-funded NGOs. The USA requires that NGOs funded from abroad are open about it. Since 1976, Indian NGOs need special permission from the authorities to receive foreign funds, and Israel's Justice Minister has proposed bill quite similar to the Russian law forcing foreign-funded NGOs to print labels on all of their official documents indicating by which "foreign entity" they are financed. Therefore, the "agent law" is not necessarily a valid measure of the Russian regime's acceptance of civil society and NGOs but rather of its fear of foreign influence that in worst case scenarios end up in "colour revolutions". Russia differs from most Western countries by having had foreign-funded NGOs dominating the NGO sector. 
According to Davies (2014), state-organised coercion takes multiple direct and indirect forms. Violence refers to martial force applied in the governing arena - as the Russian annexation of Crimea and continuing geopolitical struggles over Eastern Ukraine exemplify. Strategies for sustaining order and controlling dissidence within Russia itself - the police, Special Forces, and intelligence services also entail well-documented instances of violence. Gramsci (1971: 159-60) further described laissez faire as coercion in the form of economic compulsion: a disciplinary strategy "introduced by legislative and coercive means", placing workers at the mercy of the labour market. Compelling people to take their chances in the market is the ubiquitous form of coercion under capitalism, particularly European austerity since 2008 , and despite government hostility to some oligarchs, the market operates in the Russian economy much as it does in the West.

Administrative domination has two strands. It refers on the one hand to a hierarchical logic of rule - the capacities of a state or subdivision to secure obedience and loyalty from its population; this is sovereignty as the "taken-for-granted order of things" (Ryan 2006: 191; 6, 2014). On the other hand, administrative domination refers to routine enforcement practices and the everyday coercive techniques underpinning sovereignty: law enforcement, judicial arbitration, rent collection, and traffic management - techniques generally nonviolent in themselves, but nevertheless coercive insofar as non-compliance is criminalised. In ascertaining the significance of network governance in Russia, we need to understand how administrative domination, in both senses, operates within, alongside, and against networks. In addition to direct coercion, the governance repertoire includes what Bang (2011) calls the politics of threats (threatening and calling attention to perceived threats) and 'selective law enforcement' (Bækken 2013). The politics of threat operate through the "shadow of 
hierarchy" (Jessop 2004) - recognition of a regime's capacity to impose sanctions without necessarily doing so - or doing so selectively. The technologies of threat include everyday surveillance (such as CCTV and internet monitoring) and the logics of performance management and accountability embedded in neoliberal public services - rewards and penalties. Again, the "foreign agents law" potentially serves both as a medium of direct repression and as a source of self-discipline among NGOs.

Market governance refers to the outsourcing of public functions to profit-making corporations and the exposure of public offices to competitive discipline. It incorporates the practices of governance by contract - the implicit or explicit use of binding target-based agreements as the vehicle for coordinating and regulating governing outputs and outcomes. Market-centred governance (competition and judicially enforceable contracts) can be distinguished from hierarchical (rule-bound) governance and network governance (based on trust or resource inter-dependency). Sometimes they are mixed, as argued by Tarasenko (2015) who describes authorities combining paternalism and neo-liberalism in their relation to civil organisations thereby fostering rent-seeking as well as profit-seeking behaviour among the latter. In delineating the significance of network governance in our case studies, we also need to be sensitive to the operations of formal and informal market mechanisms in the policy areas.

In delineating the significance of network governance in our case studies, we also need to be sensitive to the operations of formal and informal market mechanisms in the policy areas. Our framework therefore treats hierarchies, markets and networks as integrative mechanisms underpinning the institutions and practices of governance, alongside indirect and direct coercion (see Table 1). As Davies (2014: 596) argued for example, the "rules of 
competition and contracts are unenforceable without courts and prisons", and Grote (2012) found that networks cannot subsist without a degree of hierarchical ordering. Equally, however, the Russian state requires and benefits from networked relations with domestically funded civil society groups, even if these are small-scale, flanking mechanisms or "invited spaces". Our research challenge, based on our expansive definition of network governance, is to explore how networks operate in Russia and comment on trajectories whether, despite the authoritarian flavour of Russian politics networking with civil society is prevalent in parts of the policy making and implementation processes.

\section{Research Findings - an Introductory Synthesis}

In this section, we apply these tools to produce an introductory synthesis of the research findings discussed in the symposium. We studied network governance in five policy areas (migration and integration, drug policy, child protection, EIA, and ethnic policies). Here, we elicit comparisons and contrasts across the articles and discuss their relevance for our proposition that even in authoritarian regimes with relatively weak civil societies, different forms of interactive governance take place, which can fruitfully be understood using the tools of network governance theories, provided these are properly contextualized.

\section{The idea of Network Governance is Prominent in Media Discourse}

First, Handå Myhre and Berg-Nordlie study representations of collaboration in Russian media discourse. What emerges is a story of interdependency between state and societal actors. They reveal a discourse in which a highly idealistic representation of the relationship between state and civil society unfolds. As in Western discourses, this representation revolves around mutual dependency and the necessity of cooperation to solve complex social problems. The dominant discourse portrays state and non-state sectors as cooperating 
in pursuit of common goals. Non-state actors are depicted not as representing interest groups, but rather as bringing a variety of resources to the table, where the goal is to reach consensus about practical solutions to social problems. In the discourse, clinics for drug addicts and counselling services for parents operated by non-state actors are represented as supplements to state-run services, whereas teaching Russian traditions and the Russian language to migrant populations, and providing assistance with formal registration in Russia, is considered primarily an NGO task. Diaspora NGOs are expected to take significant levels of responsibility for integrating immigrants. Also, the research emphasises the role played by networks in monitoring policies and their implementation. This kind of monitoring is called "public control" ("obshchestvennyi kontrol").

Media discourse therefore identifies two key policy tropes, familiar in Western European governance literatures discussed earlier. The first is a striking discursive commitment to the idea of network governance and the virtues of cooperation. The second is the assertion of responsibility for non-state actors to contribute governing resources, where the state cannot or does not wish to do so. To an extent, therefore, media discourse is redolent of international calls to collaborate and assume responsibility found in European third-way policy discourses on civil society. The detailed analyses of collaborative practice in other contributions to the symposium show the variable ways in which these injunctions are honoured and breached, spatially and across different policy areas.

\section{Patterns of Hierarchy and Network Governance}

Kropp and Schuhmann examine practices of collaboration between state and societal actors within two policy areas, ethnic polices in multi-ethnic regions and EIA. They find that the interaction between state and society is characterised by four traits: a strictly centralised 
institutional setting at all levels of governance; the presence of narrow and exclusive "state networks"; significant asymmetries between state and non-state actors; and the weak rule of law. The EIAs under study are examples of "hybrid" governance combining "horizontal" and "vertical" elements. A proper understanding of Russian governance requires a grasp of variations within this hybrid form. Kropp and Schuhmann show how authorities in different regions choose different approaches, one by enforcing "network closure" keeping critical NGO's out, the other standing back to allow a more self-regulating network emerge. Their studies of EIAs show how some authorities find it useful to facilitate horizontal network governance processes. A formally correct procedure, where all opinions are heard, is expected to give the final policy decision greater legitimacy throughout the population. The authors show how, in one case, the state intervened to make sure participatory processes were followed. On the other hand, when it was considered strategically important to deliver a particular outcome, state agencies rescinded collaboration. In some cases, there is elite capture of the networks, and there are elements of network governance in others. We find a mix of governing technologies in variable and fluid combinations.

Aasland, Berg-Nordlie, and Bogdanova develop further insights into the dynamics of network openness and network closure. Their study of migration services identified a relatively closed network built on state-led selection biases. For example, well-established diaspora organisations are preferred collaborators, despite the fact that their main constituencies are longer-standing residents and not recent immigrants. The inclusion of respected diaspora NGOs may help increase legitimacy but does not facilitate access to target groups - a case of dysfunctional network management. 
The authors find that the need for help with service delivery is one motive for authorities inviting civil society into networks. Child welfare is one policy area in which this seems to be the case. Encouraging NGOs to "produce value added" sparked off by grants is one way whereby the authorities invite NGOs in.

Being actively involved in a governance network increases the opportunity for NGOs to win contracts for service delivery. The studies of child welfare, drug use prevention, and immigration found no examples of non-state network participants being assigned decisionmaking authority. In fact, most networks were not obliged to process recommendations to formal decision-makers. In other words, they do not substitute the formal (elected) organs when it comes to decision-making, but may do it for the sake of information gathering and legitimising policy processes.

In common with Kropp and Schuhmann, Aasland, Berg-Nordlie, and Bogdanova discover differences between policy areas and regions in how governance networks operate. Immigration and drug control is more strictly governed by the federal level and gives less leeway for the networks than child welfare. They suggest that the practices of network governance are more likely to develop in donor regions - net contributors to the Federal budget - than in subsidised regions. Kropp and Schuhmann similarly found that networks function better in regions with a diverse economic structure than in regions dependent primarily one resource (e.g. gas and oil). However, other factors play a role and make for regional differences. Russia is a federation of 85 subjects. The federal subjects are not equally authoritarian - ethnically defined republics tend to be more so. Yet, Kropp and Schuhmann find that authorities in two ethnically "unruly" regions in their study chose different governance strategies. In one case, the authorities were happy to take the status of 
observers, allowing more autonomous self-regulating network to emerge. In the other region, ethnic NGOs were not allowed to participate at all. In both cases, the state chose whether to facilitate network governance as an invited space.

As our analytical framework anticipates, the articles show a variable and fluid mix of governing technologies including the coercive, the hierarchical and the exclusionary as expected, but also an element of collaboration and networking. This situation is far from the Western ideal type, where networks escape state control, compelling government to engage with other actors. But critical literatures show that the ideal type does not operate without problems in Europe either. The contrast between positive rhetoric about networks and the realpolitik of Russian governance echoes critical perspectives on the "inauthenticity" of state-sponsored networks discussed earlier. Kropp and Schuhmann and Aasland, BergNordlie and Bogdanova depict network governance as a tool deployed selectively and unevenly. Writing about New Labour in the UK, Stoker (2002) argued that its approach to local governance could be defined as "contrived randomness" - constantly changing its approach to keep local agencies on their toes. Future research might consider whether the unevenness we find in the Russian context derives from the same kind of fatalistic strategy or whether it emerges reactively, unintentionally and on account of the enormous diversity in Russian society. Either way, we are confident that the research demonstrates the value of an analytical framework, which starts from the comparability of governance challenges in different societies and which positions Russia on a continuum of practices and dilemmas familiar throughout the Anglo-European governing landscape. Networking operates in an authoritarian (hierarchical and coercive) context. It depends on how far state actors and agencies create a permissive environment. It therefore operates conditionally and instrumentally. 
The Russian variety of networking differs more in degree than in essence from the Anglo-

European archetype. Russian governance networks differ in the ways members of networks are recruited. They are invited in mainly as individuals rather than representatives of organisations and behave accordingly within the networks. Russian network closure is characterised by low acceptance of critical voices. Willingness to work constructively with the state is the condition of being kept inside the network - a tendency also noted by critics of network governance in the Anglo-European literature. It was striking that Russian media discourse uses familiar Anglophone tropes of complexity and mutual dependency to justify government-civil society networks. However, the right of the state to decide when and how to involve other actors is never questioned.

Table 1 is a simple heuristic outlining the basic parameters of state-centred, market and network modes of governing, benchmarked against our exploratory findings in Russia.

\begin{tabular}{|c|c|c|c|c|}
\hline Valued Goods & State & Market & Network & Russia \\
\hline Efficiency & $\begin{array}{l}\text { Hierarchical order, } \\
\text { state authority, } \\
\text { sovereignty. }\end{array}$ & Competition & $\begin{array}{l}\text { Network } \\
\text { governance to } \\
\text { solve complex } \\
\text { problems. }\end{array}$ & $\begin{array}{l}\text { Networks contribute to solving } \\
\text { complex problems in context of } \\
\text { state authority. Some } \\
\text { territorial and policy variations }\end{array}$ \\
\hline Participation & $\begin{array}{l}\text { Representation, } \\
\text { consultation, } \\
\text { expert committee. }\end{array}$ & $\begin{array}{l}\text { Clustering for } \\
\text { competitive } \\
\text { advantage }\end{array}$ & $\begin{array}{l}\text { Deliberation, } \\
\text { resource inter- } \\
\text { dependency }\end{array}$ & $\begin{array}{l}\text { Consultation, expert } \\
\text { committees, resource } \\
\text { interdependencies. No } \\
\text { deliberation }\end{array}$ \\
\hline Control & $\begin{array}{l}\text { Loyalty, status- } \\
\text { recognition, } \\
\text { command, force. }\end{array}$ & Contract & $\begin{array}{l}\text { Trust, affect, } \\
\text { consensus. }\end{array}$ & $\begin{array}{l}\text { State-centred-command and } \\
\text { force prominent. Networking } \\
\text { when sanctioned by authorities }\end{array}$ \\
\hline Responsibility & $\begin{array}{l}\text { Follow the rules } \\
\text { and know your } \\
\text { place }\end{array}$ & $\begin{array}{l}\text { Contributory } \\
\text { principle - } \\
\text { improve in } \\
\text { order to } \\
\text { compete }\end{array}$ & $\begin{array}{l}\text { Connect with } \\
\text { others }\end{array}$ & $\begin{array}{l}\text { NGOs follow rules in network } \\
\text { arena and contribute by } \\
\text { sharing expertise/ } \\
\text { information/labour and } \\
\text { conferring governing legitimacy }\end{array}$ \\
\hline
\end{tabular}

Table 1: Hierarchies, Markets, and Networks in Russian Social Policy: Provisional Findings 
Finally, one of the most interesting insights in all three articles is that the distinction between state and civil society is itself often hard to pin down. Actors in the same governing arena can belong to either category or both depending on their role in a particular policy process. Members of networks often see each other as experts rather than formal representatives of their organisations. We suggest that this role blurring points to a significant analytical challenge, and problematises any simplistic distinction between "state" and "civil society". When Gramsci described Eastern civil society as "gelatinous', he had in mind that the distinction with the governmental apparatus was not well developed, in contrast with the West. Yet, critical literatures on civil society in the West also point to the fact that government, corporations, and NGOs are perhaps increasingly inter-dependent and inter-woven. As Buttigieg (2005) argued, the fashionable Anglophone generalisation about civil society development as "progressive" or "democratising" does not stand up to scrutiny. The relationship between the pillars of civil society and the state is, he suggests, more often symbiotic than conflictual. It may therefore be fruitful to consider whether the hybrid governance that the Russian example demonstrates is replicated more widely in Europe. The experience of austerity and privatisation of key state functions, including sharp reductions in state support for NGOs and a service-commissioning environment, increasingly ties civil society to public sector goals under increasingly stringent performance management. This suggests that comparisons between Russian "hybrid authoritarian" and Western "privatised neo-liberal" governance could be instructive.

\section{Conclusion}

Our opening premise was scepticism towards narratives of Russian exceptionalism. Following this intuition, our study sought to consider the proposition that the tools for 
analysing governance familiar in Europe could fruitfully be used to study at least a limited range of government-civil society relations in Russia. Our principal insight and contribution to the literature on Eastern Europe is to have shown that a common frame of analysis opens up the prospects for fruitful dialogue and comparison. The Russian context is different, the dilemmas and technologies applied in trying to address them often familiar. We make three points in conclusion.

First, networking with civil society groups matters in Russian social policy and is comparable with networking in Western Europe. It is sanctioned by the state and prominent in media discourse, but applied instrumentally and selectively. As the symposium shows, it may ebb and flow in different areas and different regions. The dilemma is that if the state erodes civil society autonomy, rolls back networking and excludes critical voices, then it will lack reliable information required to develop successful policies. Second, as Rhodes (1997) put it, it is the mix that matters. While governance enthusiasts in Europe have been guilty of exaggerating the importance of networks, studies of Russian authoritarianism may do the opposite in failing to recognise the limits of state and corporate power and the dependence of the regime on others to deliver goods that it, and citizens, value. Third, however, the tentative influence of civil society in Russian social policy is not necessarily a force for democratisation. Critical voices are silenced and excluded. Moreover, the blurring of roles highlights an enduring problem for studies of government and civil society in Russia and far beyond. When is the distinction meaningful? What impact does the remaking of relations between government, market, and citizen in conditions such as European austerity have on the capacity of NGOs to speak truth to power? Our research opens up this and other questions that we hope will be taken up in future comparative studies involving Russia. 


\section{Funding}

This article was funded by the Research Council of Norway's NORRUSS Programme [grant number 220615].

\section{References}

Ansell, Chris and Alison Gash. 2008. "Collaborative Governance in theory and Practice". Journal of Public Administration Research and Theory 18 (4): 543-571.

Bækken, Håvard 2013. Selective Law Enforcement in Russian Politics 2007-2011 - Legal Action for Extra-Legal Purposes. PhD Dissertation. Faculty of Humanities - University of Oslo.

Bang, H. 2011. "The politics of threats: late modern politics in the shadow of neoliberalism". Critical Policy Studies. 5 (4): 434-448.

Belyaeva, Nina and L. Proskuryakova 2008. "Civil Society Diamond: Civicus Civil Society Index

- Shortened Assessment Tool, Report for the Russian Federation". Moscow: Interlegal Foundation.

Bindman, E. 2015. 'The state, civil society and social rights in contemporary Russia', East European Politics, 31 (3): 342-360.

Borgatti, Stephen P., Ajay Mehra, Daniel J. Brass, Giuseppe Labianca 2009. “Network Analysis in the Social Sciences". Science 323 (5916): 892-895.

Bray, D. 2006. "Building "community": new strategies of governance in urban China". Economy and society 35 (4): 530-549. 
Buttigieg, J.A. 2005. "The Contemporary Discourse on Civil Society: A Gramscian Critique" Boundary 32(1) 33-52.

Chebankova, Elena 2013. Civil Society in Putin's Russia. London: Routledge

Cook K, Hardin R, Levi M. 2007. Cooperation without Trust? Russell Sage Foundation: New York.

Cook, Linda J. 2013. Postcommunist Welfare States: Reform Politics in Russia and Eastern Europe. Ithaca, NY: Cornell University Press

Crotty, Jo, Sarah Marie Hall \& Sergej Ljubownikow. 2014. “Post-Soviet Civil Society Development in the Russian Federation: The Impact of the NGO Law", Europe-Asia Studies 66 (8): 1253-1269.

Daucé, Françoise. 2014. "The Government and Human Rights Groups in Russia: Civilized Oppression?". Journal of Civil Society 10 (3): 239-254.

Davies, Jonathan S. 2012. "Network Governance Theory: A Gramscian Critique". Environment and Planning A 44 (11): 2687-2704.

Davies J. S. 2014. "Coercive Cities: Reflections on the Dark Side of Urban Power in the 21st Century". Journal of Urban Affairs 36(s2): 590-599.

Davies, Jonathan S and André Spicer. 2015. “Interrogating Networks: Towards an Agnostic Perspective on Governance Research", Environment and Planning C: Government and Policy. 33: 223-238. 
Elbakidze, Marine, Per Angelstam, Camilla Sandström, and Robert Axelsson, Robert (2010). "Multi-stakeholder collaboration in Russian and Swedish model forest initiatives: adaptive governance toward sustainable forest management?", Ecology and Society. 15:2, 1-20

Evans, Alfred. 2012. "Protest and civil society in Russia - the struggle for the Khimki Forest". Communist and Post-Communist Studies 45 (3-4): 233-242.

Evans, Mark and Jonathan Davies. 1999. “Understanding Policy Transfer: A Multi-Level, Multi-Disciplinary Perspective", Public Administration 10 (2): 361-385.

Geddes, M. 2006. 'Inter-organizational relationships in local and regional development partnerships', in S. Cropper, M. Ebers, C. Huxham and P. Smith Ring (eds). The Oxford Handbook of inter-organizational relations. Oxford. Oxford University Press.

Gramsci, Antonio. 1971. Selections from Prison Notebooks. London: Lawrence \& Wishart.

Granovetter, M. 1983. "The Strength of Weak Ties: A Network Theory Revisited".

Sociological Theory 1: 201-233

Grote, J.R. 2012. Horizontalism, vertical integration and vertices in governance networks. Stato e Mercato 94(1): 103-134

Flores, A. 2005. Local democracy in modern Mexico. A study in participatory methods. Bury St Edmonds: Arena Books

Hedlund, Stefan. 2001. "Property Without Rights - Dimensions of Russian Privatisation". Europe-Asia Studies 53 (2): 213-38.

HemmJeent, Julie. 2012. “Nashi, Youth Voluntarism, and Potëmkin NGO's - Making Sense of Civil Society in Post-Soviet Russia". Slavic Review 71 (2): 234-260. 
Henry, Laura and Lisa Sundstrom. 2006. "Russian Environmentalists in Civil Society". In Change and Continuity in Russian Civil Society: A Critical Assessment, edited by Alfred Evans, Laura Henry, and Lisa McIntosh Sundstrom. Armonk, NY: M.E. Sharpe.

Huxham, Chris, and Siv Vangen. 2005. Managing to collaborate: The theory and practice of collaborative advantage. London: Routledge.

Jakobson, Lev and Sergey Sanovich. 2010. "The Changing Models of the Russian Third Sector - Import Substitution Phase". Journal of Civil Society 6 (3): 279-300.

Jessop, B. 2004. “Multi-level governance and multi-level meta-governance”. In Multi-level Governance, edited by I. Bache and M. Flinders. Oxford: Oxford University Press.

Kononenko, Vadim and Arakady Moshes. 2011. Russia as a Network State What Works in Russia When State Institutions Do Not? London: Palgrave Macmillan

Malia, M. 1999. Russia under Western Eyes: from the Bronze Horseman to the Lenin Mausoleum. Cambridge, Mass.: The Belknap Press.

Marsh, D. 2008. "Understanding British government: analysing competing models". British Journal of Politics and International Relations 10 (2): 251-268.

Mayntz, Renate. 1993. "Governing failures and the problem of governability: Some comments on a theoretical paradigm". In Modern governance: New government-society interactions, edited by J. Kooiman. London: Sage.

Osborne, Stephen P, ed. 2010. The new public governance? London: Routledge

Owen, Catherine. 2015. "Consentful contention" in a corporate state: human rights activists and public monitoring commissions in Russia, East European Politics. 31 (2): 274-293 
Petrone, Laura. 2011."Institutionalizing Pluralism in Russia: A New Authoritarianism?". Journal of Communist Studies and Transition Politics 27 (2): 166-194.

Petrov, Nikolay, Maria Lipman \& Henry E. Hale. 2010. “Overmanaged Democracy in Russia: Governance Implications of Hybrid Regimes". Russia and Eurasia Program Number 106. Washington D.C.: Carnegie Endowment Petrov, Nikolay, Maria Lipman \& Henry E. Hale. 2014. "Three dilemmas of hybrid regime governance: Russia from Putin to Putin". Post-Soviet Affairs 30 (1): 1-26.

Pierre, J. and Stoker, G. 2002. "Toward multi-level governance". In P. Dunleavy, A. Gambler, R. Heffernan, I. Holliday and G. Peele (eds) Developments in British Politics 6. Palgrave: Basingstoke.

Pipes, Richard. 1995. Russia Under the Old Regime. London: Penguin Pipes, Richard. 1999. Property and Freedom. London: The Harvill Press Prognostika 2011. 2012. "Resul'taty sotsiologicheskoe issledovanie na temu Sotsial'noorientirovannye NKO Samarskoy oblasti v 2011 godu - sostoyanie, tendentsii, perspektivy" [Results of sociological research on socially-oriented non-commercial organisations in the Samara region in 2011 - conditions, tendencies, perspectives]. Samara: GU Dom Druzhby Narodov/Obshchestvennaya Palata Samarskoy Oblasti/OOO Prognostika,

Raab,. J. and H. B. Milward. 2013. "Dark Networks as Problems". Public Administration Research and Theory. 13 (4): 413-439. 
Randma-Liiv, Tiina. 2008. “New Public Mangement versus Neo-Weberian State in Central and Eastern Europe". Paper presented at the Trans-European Dialogue - 1 Towards the NeoWeberian State? Europe and Beyond, Tallinn, 31 January - 1 February.

Randma-Liiv, Tiina, Vitalis Nakrošis and Hajnal György. 2011. "Public Sector Organization in Central and Eastern Europe: From Agencification to De-Agencification". Transy/vanian Review of Administrative Sciences Special Issue: 160-175.

Rhodes, R. A. W. 1997. Understanding governance. Policy networks, governance, reflexivity and accountability. Maidenhead: Open University Press.

Roberts, Nancy. 2000. "Wicked problems and network approaches to resolution". International Public Management Review 1 (1):1-19.

Ryan, K. 2006. "Hegemony and the power to act". In: Hegemony and Power: Consensus and Coercion in Contemporary Politics edited by M. Haugaard and H. H. Lentner, 191-210. New York: Lexington Books.

Røiseland, Asbjørn. 2011. “Understanding local governance - institutional form of collaboration". Public Administration 89(3): 879-893.

Sakwa, Richard. 1998. "Russian Political Evolution: A Structural Approach". In Rethinking the Soviet Collapse: Sovietology, the Death of Communism and the New Russia, edited by Michael Cox. London: Pinter

Sakwa, Richard. 2010a. The Crisis of Russian Democracy - The Dual State, Factionalism and the Medvedev Succession, Cambridge: Cambridge University Press

Sakwa, Richard. 2010b. "The Dual State in Russia”. Post-Soviet Affairs 26 (3): 185-206. 
Shlapentokh, V. 2003. “Hobbes and Locke at Odds in Putin's Russia”. Europe-Asia Studies 55 (7): 981-1007

Skelcher, C., N. Mathur and M. Smith, 2005. 'The public governance of collaborative spaces: discourse, design and democracy', Public administration, vol 83, no 3, pp. 573-596.

Sørensen, Eva, and Jacob Torfing, eds. 2007. Theories of democratic network governance. Houndmills. Basingstoke, Houndmills: Palgrave.

Sørensen, Eva and Jacob Torfing. 2011. "Enhancing collaborative innovation in the Public Sector". Administration \& Society 43(8): 842-868.

Stark, David \& László Bruszt. 1998. Postsocialist Pathways. Cambridge: Cambridge University Press.

Stoker, G. 2002. 'Life is a lottery: New Labour's strategy for the reform of devolved governance'. Public Administration. 80 (3): 417-34

Stone, C.N. 2009. "Who is Governed? Local Citizens and the Political Order of Cities". In Theories of Urban Politics edited by J.S. Davies and D.L. Imbroscio, 257-273. London: Sage, 2nd edition.

Stuvøy, Kirsti. 2014. "Power and Public Chambers in the development of civil society in Russia". Communist and Post-Communist Studies 47 (3-4): 409-419.

Tarasenko, A. V. 2010. “Deyatelnost' obshchestvennykh palat v regionakh Rossii: Effektivnost' vs. fiktivnost'" [Activities of the public chambers in Russia's regions: effectiveness versus fiction]. Politiya 1 (56): 80 - 88 . 
Tarasenko, A. V. 2015. 'Russian welfare reform and social NGOs - strategies for claimmaking and service provision in the case of St Petersburg', East European Politics 31(3): 294313.

Taylor, Brian D. 2014. "Police reform in Russia - the policy process in a hybrid regime". PostSoviet Affairs 30 (2-3): 226-255.

Thomas, Peter. 2009. The Gramscian Moment: Philosophy, Hegemony and Marxism. Leiden: Brill.

Tipalo, Elena E. 2011. “Obshestvennaia Palata Rossiyskoy Federatsii kak institut grazhdanskogo obshchestva" [Public Chamber of the Russian Federation is an institution of the civil society], avtoreferat dissertatsii [formal resume of the thesis], Southern Federal University, Rostov-na-Donu.

Vasil'eva, Tat'iana A. 2009. Vzaimodeystvie gosudarstvennykh organov vlasti i negosudarstvennykh nekommercheskikh organizatsiy kak institutov grazhdanskogo obshchestva v sovremennoy Rossii [Interaction between state authorities and non-state, non-commercial organisations as institutions of civil society in contemporary Russia], avtoreferat dissertatsii [formal resume of the thesis], Faculty of Political Science and Social Policy - Russian State Social University, Moscow. 
